Volume 10, Nomor 1, Mei 2018, pp 53-61 Copyright (C) 2017 Jurnal Akuntansi Maranatha, Program Studi Akuntansi, Fakultas Ekonomi, Universitas Kristen Maranatha. ISSN 2085-8698 | e-ISSN 2598-4977. http://journal.maranatha.edu

\title{
Strategic Planning dan Balanced Scorecard serta Penerapannya pada Restoran Cepat Saji Wendy's
}

\author{
Felisia \\ Fakultas Ekonomi Program Studi Akuntansi-Univ.Katolik Parahyangan \\ (Jl. Ciumbuleuit No. 94, Bandung) \\ felisia.liu@unpar.ac.id
}

\begin{abstract}
Organizations need to improve their performances in order to compete in global market. To improve performance, organizations need strategies and performance evaluation measurements. Strategies must be allied within the industry which the organizations competed in. Strategies are formulated by evaluating external factors such as opportunities and threats, and internal factors such as strengths and weaknesses. After determining strategies, organizations formulate strategic planning to implement the strategies determined. Organizations also design strategy maps and balanced scorecards to describe how they could create value by connecting their strategic objectives. Fast food industries have grown in the past years. According to QSR Magazine in 2012, Wendy's is one of the top ten highest rated food chains, next to McDonalds, Kentucky Fried Chicken, Burger King, Pizza Hut, Subway, Dominos Pizza, Strabucks, Dunkin Donuts, and Dairy Queen. This article analyzes strategies, strategy map, and balanced scorecard in Wendy's. Through this article, readers will know the importance of strategic planning, strategy map, and balanced scorecard for organizations.
\end{abstract}

Keywords: Strategic Planning, Strategy Map, Balanced Scorecard 


\section{Pendahuluan}

Masyarakat Ekonomi ASEAN membuka peluang bagi negara-negara di ASEAN untuk meningkatkan arus perdagangan. Di samping peluang, tantangan bagi perusahaan-perusahaan di negara ASEAN juga meningkat. Perusahaan dituntut untuk dapat meningkatkan kinerjanya agar dapat bersaing. Untuk menghasilkan kinerja yang baik tentunya perusahaan memerlukan strategi serta alat pengukuran kinerja yang tepat. Dengan pengukuran kinerja yang tepat, hasil evaluasi kinerja dapat menjadi umpan balik untuk perbaikan strategi yang kemudian diwujudkan dalam kinerja perusahaan.

Strategi harus disesuaikan dengan jenis industri dimana perusahaan bersaing. Perusahaan memformulasikan strategi dengan cara mengevaluasi faktor eksternal (Opportunities, Threats) dan faktor internal perusahaan (Strengths, Weaknesses). Setelah menentukan strategi yang kemudian dituangkan dalam strategic planning, perusahaan dapat menerapkan strategi. Setelah menerapkan strategi, perusahaan kemudian memerlukan sistem pengukuran kinerja untuk melihat sejauh mana keberhasilan perusahaan dalam melaksanakan strategic plan yang telah disusun tersebut.

Organisasi memerlukan sistem pengukuran kinerja yang efisien dan komprehensif. Untuk mengukur kinerja tidak cukup hanya menggunakan beberapa ukuran yang dipilih secara acak. Balanced scorecard merupakan sistem pengukuran kinerja

yang komprehensif, terdiri dari beberapa perspektif yang saling berhubungan dan menggambarkan kinerja tidak hanya keuangan tapi juga non keuangan.

Penelitian ini dibuat dengan tujuan untuk memahami strategic planning, balanced scorecard serta bagaimana penerapannya dalam dunia nyata. Penulis akan menggunakan restoran cepat saji Wendy's sebagai contoh perusahaan untuk dianalisa. Di negara maju dan kota-kota besar, individu dituntut untuk menyelesaikan pekerjaan dengan lebih cepat sehingga tidak jarang waktu luang seperti waktu makan siang dipersingkat. Restoran cepat saji merupakan salah satu pilihan untuk mendapatkan makanan dalan waktu singkat. Oleh karena itu popularitas restoran cepat saji terus meningkat begitu pula halnya dengan di Indonesia. Berdasarkan survey yang dilakukan oleh QSR Magazine pada 2012, Wendy's merupakan salah satu dari sepuluh besar restoran cepat saji di dunia, berdampingan dengan McDonalds, Kentucky Fried Chicken, Burger King, Pizza Hut, Subway, Dominos Pizza, Strabucks, Dunkin Donuts, dan Dairy Queen. Penulis akan menganalisa bagaimana penerapan strategic planning serta bagaimana penilaian kinerja dengan menggunakan balanced scorecard pada restoran cepat saji Wendy's.

\section{Kerangka Teoritis}

\section{Definisi Strategi}

Menurut Anthony dan Govindarajan (2007:56), strategi adalah arah yang perlu dilaksanakan oleh organisasi untuk mencapai tujuannya. Setiap organisasi yang teratur dengan baik pasti memiliki strategi meskipun kadang tidak dinyatakan secara eksplisit. Seperti yang diungkapkan Kenneth R. Andrews dalam bukunya yang berjudul The Concept of Corporate Strategy dan dikutip oleh Anthony dan Govindarajan (2007:57), strategi diformulasikan dengan cara mengevaluasi faktor eksternal yang berupa kesempatan dan ancaman, dengan faktor internal yang berupa kekuatan serta kelemahan perusahaan. Kekuatan utama perusahaan yang diseimbangkan dengan peluang yang ada di pasar akan menghasilkan strategi bagi perusahaan. 


\section{Definisi Strategic Planning}

Menurut Anthony dan Govindarajan (2007:330-331), strategic planning merupakan proses yang dilakukan organisasi dalam memutuskan program kerja apa saja yang akan dilakukan serta alokasi sumber daya yang diperlukan ke dalam tahapan program kerja tersebut. Hasil dari strategic planning adalah strategic plan atau dapat juga dituangkan dalam strategy map. Strategy map merupakan diagram yang menggambarkan strategi perusahaan. Dengan strategy map, setiap karyawan dapat mengetahui strategi perusahaan secara keseluruhan serta dapat memahami dampak dari hasil yang mereka kerjakan terhadap tujuan perusahaan.

\section{Definisi Balanced Scorecard}

Menurut Horngren (2015:492), balanced scorecard dapat menerjemahkan misi dan strategi perusahaan ke dalam satu set pengukuran kinerja yang merupakan kerangka untuk penerapan strategi.

Hilton dan Platt (2015:515) menyatakan manajer memerlukan sistem pengukuran kinerja yang tidak hanya menggambarkan ukuran keuangan tapi juga non keuangan secara komprehensif. Ukuran keuangan menggambarkan hasil dari kinerja masa lampau. Hasil ini merupakan hasil yang penting bagi pemilik perusahaan, kreditur, karyawan serta pihak pengguna laporan keuangan lainnya. Di samping kinerja keuangan, kinerja non keuangan juga perlu diperhatikan. Kinerja non keuangan menggambarkan aktivitas saat ini yang akan mempengaruhi hasil kinerja keuangan di masa yang akan datang. Oleh karena itu, perusahaan memerlukan sistem pengukuran kinerja yang dapat menyeimbangkan ukuran keuangan dan non keuangan yang disebut sebagai balanced scorecard.

\section{Perspektif dalam Balanced Scorecard}

Pada umumnya balanced scorecard memiliki empat perspektif (Horngren
2015:500). Empat perspektif tersebut adalah:

\section{Financial}

Dalam perspektif ini, keberhasilan strategi diukur dalam bentuk profit yang dicapai perusahaan. Ukuran yang digunakan dapat berupa profit margin, Return on Assets, cash flow.

2. Customer

Perspektif ini mengidentifikasikan target pelanggan, segmentasi pasar serta keberhasilan perusahaan dalam menguasai segmen ini. Ukuran yang digunakan dapat berupa market share, jumlah pelanggan baru, tingkat kepuasan pelanggan.

3. Internal business

Fokus dari perspektif ini adalah pada operasi internal perusahaan yang dapat memberikan nilai tambah bagi pelanggan yang pada akhirnya diharapkan dapat berdampak pada peningkatan kinerja keuangan. Ukuran yang digunakan dapat berupa waktu produksi, ketepatan waktu pengiriman barang ke pelanggan.

4. Learning and growth

Perspektif ini mengidentifikasikan kemampuan perusahaan untuk mencapai proses bisnis internal perusahaan yang baik yang pada akhirnya dapat meningkatkan nilai tambah bagi pelanggan dan pemegang saham. Ukuran yang digunakan dapat berupa tingkat kepuasan karyawan, tingkat keberhasilan sistem informasi perusahaan, tingkat kemampuan atau keahlian karyawan yang diukur lebih lanjut melalui pelatihan karyawan.

Pertimbangan dalam Menyusun Balanced Scorecard

Seperti yang dibahas oleh Anthony dan Govindarajan dalam bukunya yang berjudul Management Control Systems, dalam menyusun balanced scorecard, perusahaan harus mempertimbangkan kebutuhan dari para stakeholders dan menggabungkannya dalam ukuran-ukuran yang menggambarkan 
outcome dan driver measures, financial dan non financial measures, serta internal dan eksternal measures. Berikut akan dibahas lebih lanjut.

1. Outcome dan driver

Outcome menggambarkan hasil dari strategi atau disebut juga lagging indicators sedangkan driver menggambarkan kemajuan dari penerapan strategi atau disebut juga leading indicators. Dalam balanced scorecard harus tergambarkan dengan jelas apa saja yang menjadi driver dan apa saja outcome yang diharapkan dari driver tersebut. Dengan kata lain dapat dilihat hubungan sebab akibat dari setiap tindakan yang dilakukan.

2. Financial dan non financial

Balanced scorecard harus menggambarkan ukuran keuangan dan non keuangan secara seimbang. Dengan memahami balanced scorecard manajer diharapkan dapat mengambil tindakan yang pada akhirnya dapat meningkatkan kinerja keuangan. Hal ini dapat dicapai dengan melakukan tindakan yang berhubungan dengan ukuran kinerja non keuangan.

3. Internal dan Eksternal

Balanced scorecard harus menggambarkan ukuran internal dan eksternal secara seimbang juga. Contoh ukuran kinerja internal adalah proses bisnis perusahaan sedangkan contoh ukuran kinerja eksternal adalah dari sisi pelanggan seperti misalkan tingkat kepuasan pelanggan.

\section{Pembahasan}

\section{Sistem Pengendalian Manajemen dan Strategi dalam Perusahaan}

Suatu organisasi dapat dijalankan secara tersentralisasi maupun desentralisasi. Dalam organisasi yang dijalankan secara desentralisasi, pemilik atau sering juga disebut principal mempercayakan jalannya kegiatan pada pelaksana atau sering juga disebut agent. Pemegang saham merupakan pihak principal dalam perusahaan, sedangkan chief executive officer merupakan pihak agent. Principal mendapatkan informasi tentang kegiatan perusahaannya melalui laporan yang diberikan oleh agent. Hal ini dapat menimbulkan asimetri informasi, dimana agent memiliki informasi lebih banyak mengenai kegiatan operasional perusahaan dan principal hanya mengandalkan laporan dari agent. Di samping masalah asimetri informasi, principal dan agent seringkali memiliki perbedaan kepentingan. Dimana principal lebih mementingkan tingkat pengembalian dari sisi keuangan yang menyebabkan principal lebih bersikap risk neutral, sedangkan agent lebih mementingkan kemakmuran dirinya sendiri yang dapat diperoleh dari kompensasi secara finansial maupun dari sisi non finansial lainnya, seperti waktu kerja yang fleksibel dan tersedianya leisure time yang memadai. Hal ini menyebabkan agent cenderung untuk bersikap risk averse. Perbedaan kepentingan, sikap terhadap risiko, dan asimetri informasi menjadi latar belakang perlunya sistem pengendalian manajemen.

Sistem pengendalian manajemen terdiri dari beberapa tahapan seperti yang digambarkan di bawah ini:

\section{Formulasi Strategi}

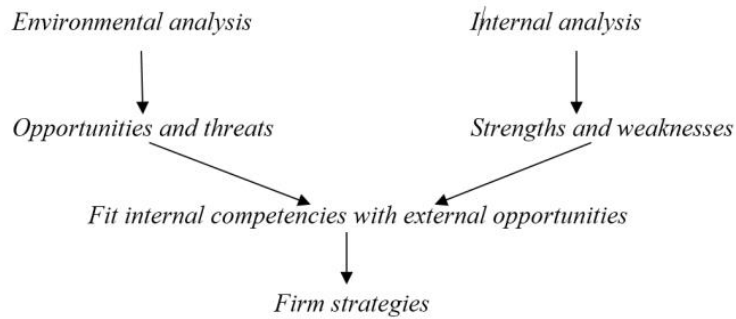

Sumber: Anthony dan Govindarajan (2007:57)

Setelah menentukan strategi, perusahaan membuat strategic planning. Dalam strategic planning, perusahaan memutuskan program-program apa saja 
yang akan dilaksanakan serta bagaimana alokasi sumber daya dalam pelaksanaan setiap tahapan program yang direncanakan akan dilakukan. Program kegiatan akan disesuaikan dengan goal dari perusahaan. Jika rancangan program yang akan dilaksanakan telah tersusun, tahapan selanjutnya yang dilakukan perusahaan adalah membuat anggaran. Dalam anggaran tergambarkan sumber daya yang direncanakan untuk digunakan beserta hasil yang diharapkan dapat dicapai. Strategic plan dan anggaran kemudian akan dikomunikasikan ke seluruh jajaran dalam perusahaan untuk kemudian dilaksanakan. Hasil dari pelaksanaan akan dikaji ulang dan dibuat rencana perbaikan untuk pelaksanaan periode berikutnya.

Dalam pelaksanaan program kegiatan perusahaan diperlukan suatu alat bantu untuk menerjemahkan strategi dan rencana perusahaan. Perusahaan dapat membuat strategy map untuk menggambarkannya. Kemudian perusahaan dapat juga membuat balanced scorecard untuk memperjelas strategy map. Dalam balanced scorecard rencana perusahaan yang dibuat dalam strategy map diperjelas ke dalam bentuk kegiatan, dan sasaran yang lebih mudah untuk dimengerti. Selain berfungsi untuk menerjemahkan strategi, balanced scorecard juga dapat digunakan untuk mengukur kinerja perusahaan. Dalam balanced scorecard, kinerja perusahaan dapat dilihat dari empat perspektif yang saling berhubungan, yaitu financial, customer, internal business process, dan learning and growth. Namun perspektif dalam balanced scorecard tidaklah terbatas hanya kepada keempat komponen ini. Perspektif dalam balanced scorecard dapat disesuaikan dengan kondisi perusahaan.

Penerapan Strategy Map dan Balanced Scorecard pada Restoran Cepat Saji Wendy's

Wendy's adalah jaringan restoran dan waralaba makanan internasional yang mengkhususkan produksinya dalam bentuk produk hamburger. Wendy's selalu mengedepankan kualitas dari produknya seperti semboyan dari Wendy's yaitu "Quality is our recipe". Wendy's didirikan pada tahun 1969 oleh Dave Thomas di Dublin, Ohio. Wendy's sekarang ini merupakan restoran hamburger berantai terbesar ketiga di dunia, dengan hampir 6.700 restoran, kios pengantaran-ambil ke luar di lebih dari 27 negara. Mission Statement dari Wendy's adalah "Do The Right Thing!'.Melakukan hal yang benar meliputi peningkatan sumber daya manusia sesuai dengan budaya dan melibatkan karyawan dalam berbagai hal. Sementara visi dari Wendy's adalah secara kontinu menumbuhkan stakeholder value melalui peningkatan kekuatan dari brand yang dimiliki oleh restoran. Untuk dapat menentukan strategi, perusahaan terlebih dahulu melakukan analisis Strengths, Weaknesses, Opportunities, Threats. Analisis kekuatan, kelemahan, kesempatan, serta ancaman yang dimiliki perusahaan ini seringkali juga disebut analisis SWOT. Berikut adalah analisis SWOT dari Wendy's. 


\section{Analisis SWOT Wendy's}

SWOT Analysis Matrix

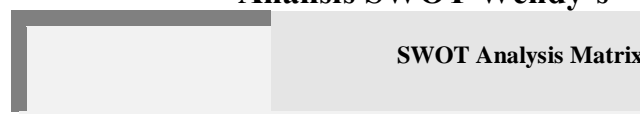

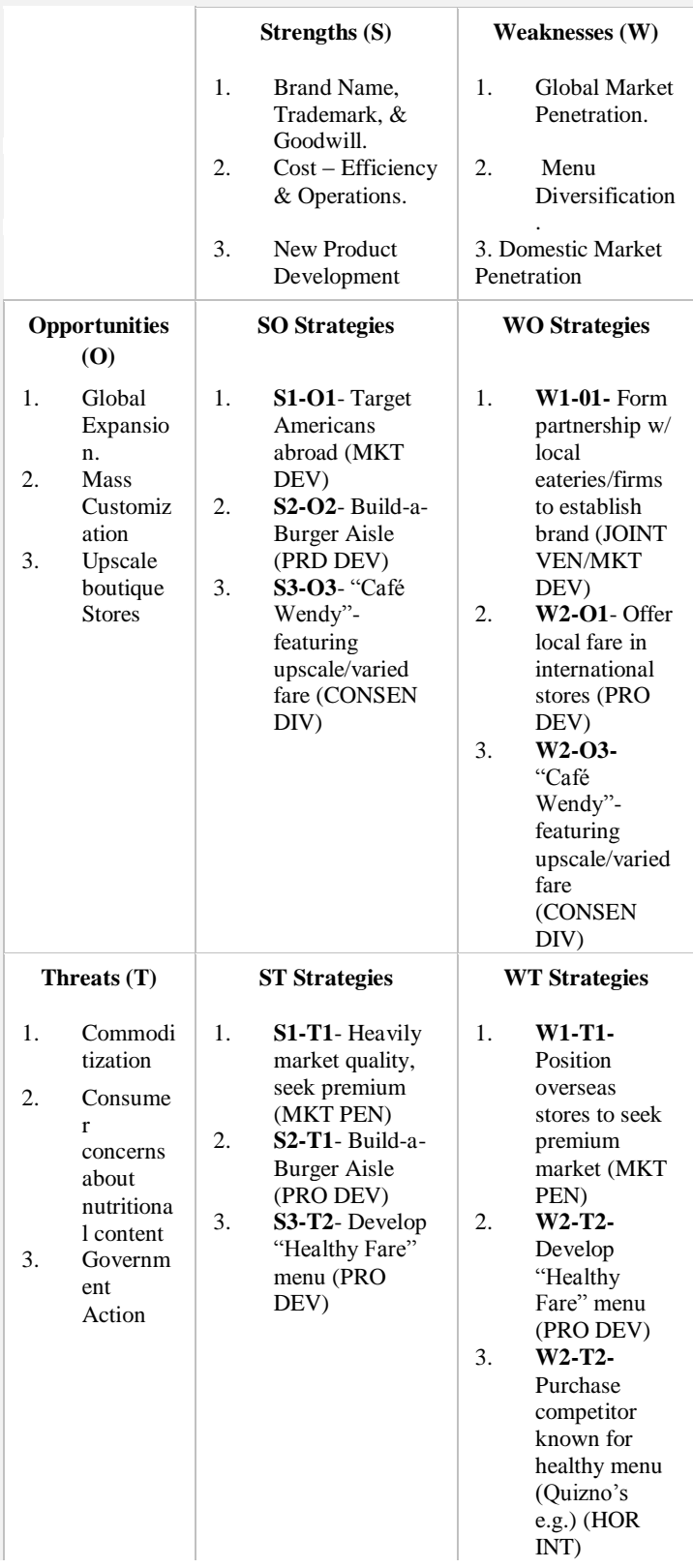

Sumber : Ajmi et al. (2013)
Dari tabel analisis SWOT di atas, dapat dilihat bahwa Wendy's memiliki kekuatan yang salah satunya berupa efisiensi dalam biaya operasi dan pengembangan produk baru. Sesuai dengan analisis SWOT, Wendy's masih memiliki kesempatan untuk melakukan pengembangan dan perbaikan. Pengembangan ini dapat diterjemahkan dalam strategy map dan balanced scorecard. Strategy map dan balanced scorecard dapat menggambarkan area-area mana saja yang memerlukan perbaikan dan langkah apa saja yang dapat diambil untuk melakukan perbaikan tersebut. Berikut strategy map dari Wendy's.

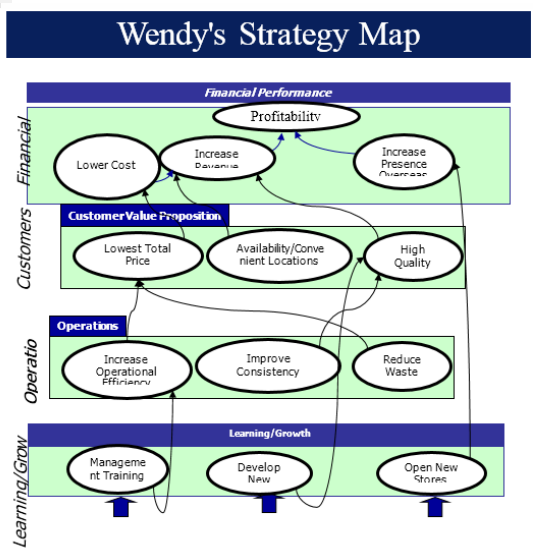

Sumber : Ajmi et al. (2013)

Strategy map dibuat berdasarkan informasi dari analisis SWOT. Melalui strategy map, kita dapat mengetahui harapan dan tujuan dari tindakan yang akan dilakukan. Sebagai contoh, dapat dilihat bahwa Wendy's memiliki kekuatan berupa pengembangan produk baru. Melalui pengembangan produk baru yang dilakukan (perspektif learning/growth), Wendy's memiliki harapan untuk dapat terus menghasilkan produk yang memiliki kualitas tinggi (perspektif customer), yang kemudian diharapkan dapat meningkatkan pendapatan dan profitabilitas (perspektif financial). Kekuatan lainnya yang dimiliki 
Wendy's adalah efisiensi biaya operasional. Dengan meningkatkan efisiensi operasi (perspektif operations), diharapkan harga produk dapat menjadi lebih rendah tanpa mengabaikan kualitas (perspektif customer), yang kemudian pada akhirnya diharapkan dapat meningkatkan profitabilitas (perspektif financial). Selain dari sisi kekuatan, Wendy's memiliki kelemahan dalam hal penetrasi pasar namun kesempatan untuk melakukan ekspansi secara global juga masih terbuka. Dengan melihat hal ini, Wendy's membuat strategi untuk membuka gerai baru (perspektif learning/growth). Melalui pembukaan gerai-gerai baru ini, diharapkan keberadaan Wendy's di berbagai belahan dunia dapat meningkat yang pada akhirnya dapat meningkatkan profitabilitas (perspektif financial).

Strategy map menggambarkan hasil yang diharapkan dapat terjadi dari tindakan yang dilakukan. Namun rincian dari tujuan, target, ukuran keberhasilan serta langkah-langkah untuk mencapainya masih perlu dijabarkan lebih lanjut agar seluruh anggota organisasi dapat mengambil tindakan yang sesuai dengan goals dari perusahaan. Tujuan, target, ukuran keberhasilan serta langkah-langkah ini dapat digambarkan dalam bentuk balanced scorecard. Berikut contoh balanced scorecard dari Wendy's.

\section{Balanced Scorecard dari restoran cepat saji Wendy's}

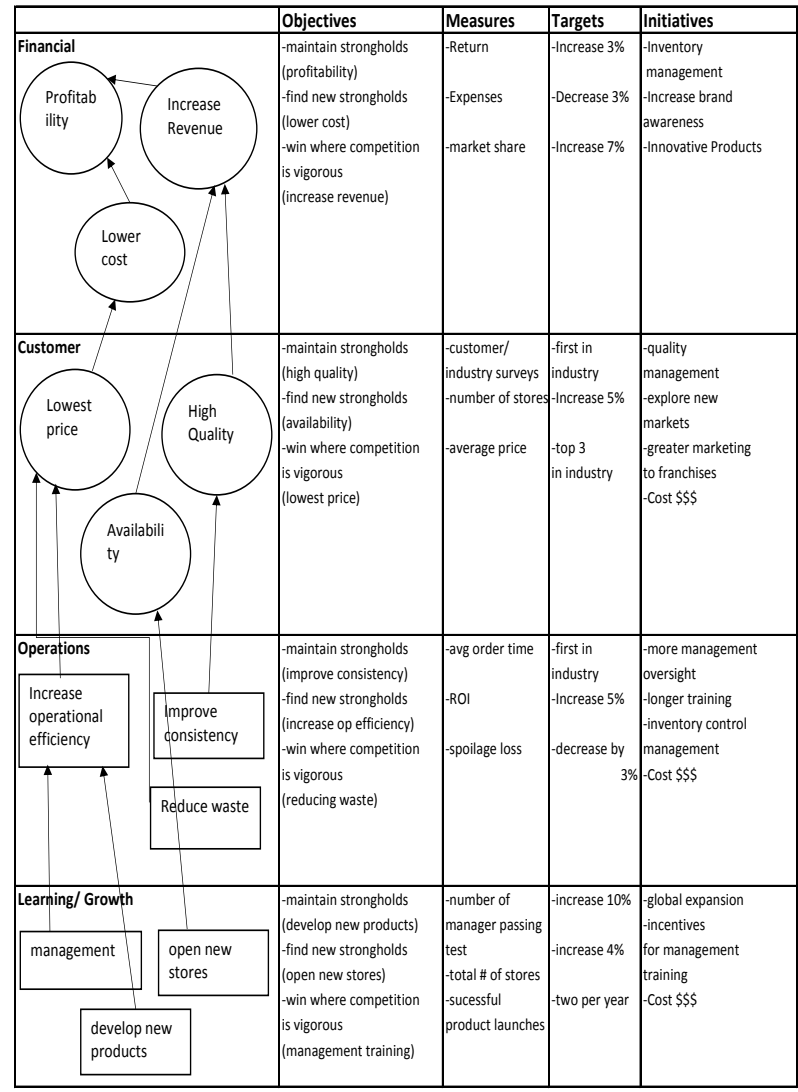

Sumber : Ajmi et al. (2013)

Dari balanced scorecard di atas, sebagai contoh dapat dilihat dari perspektif learning/ growth, tujuan dari Wendy's adalah untuk mempertahankan kekuatan yang dimiliki yaitu dengan terus mengembangkan produk baru. Ukuran keberhasilan yang ditetapkan adalah dengan suksesnya dilakukan dua buah peluncuran produk baru setiap tahunnya. Peluncuran produk baru ini tentunya memerlukan biaya dan Wendy's harus dapat meningkatkan efisiensi biaya produksi di satu sisi, dan mempertahankan konsistensi kualitas di sisi lainnya. Dengan adanya efisiensi biaya dan konsistensi kualitas, total biaya diharapkan 
dapat menurun namun kualitas dapat tetap baik. Hal ini diukur dengan target berupa keberhasilan Wendy's dalam industri makanan cepat saji yang diperoleh melalui survey pelanggan. Langkah tindakan yang dapat dilakukan untuk mencapai hal ini adalah melalui quality management. Pada akhirnya diharapkan profitabilitas dapat meningkat dimana ukuran keberhasilan dari profitabilitas ini berupa peningkatan tingkat pengembalian modal sebesar $3 \%$.

\section{Simpulan dan Saran}

\section{Simpulan}

Suatu perusahaan memerlukan strategi untuk mencapai tujuan. Pada perusahaan yang berorientasi laba, tujuan utama dari perusahaan tentunya adalah untuk meningkatkan laba. Untuk dapat mencapai laba, perusahaan harus menentukan strategi yang tepat. Perusahaan terlebih dahulu harus menentukan kekuatan, kelemahan, kesempatan serta ancaman yang dimilikinya sebelum merumuskan strategi. Analisis ini dinamakan analisis SWOT (Strengths, Weaknesses, Opportunities, Threats). Dengan mempertimbangkan faktor internal berupa Strengths dan Weaknesses, serta menyeimbangkannya dengan faktor eksternal berupa Opportunities dan Threats, perusahaan dapat merumuskan strategi yang akan ditempuh. Strategi kemudian dapat diperjelas melalui strategic planning yang digambarkan dalam strategy map. Melalui strategy map, perusahaan dapat menggambarkan hasil dan harapan dari tindakan yang akan dilakukan, yang pada akhirnya berujung pada peningkatan profitabilitas. Strategy map dapat diperjelas dengan bantuan balanced scorecard. Balanced scorecard menerjemahkan strategi perusahaan kedalam ukuran-ukuran target pencapaian yang lebih eksplisit serta langkah-langkah yang dapat ditempuh untuk mencapainya. Balanced scorecard memiliki perspektif dimana antar perspektif memiliki hubungan sebab akibat. Dalam balanced scorecard, ukuran-ukuran yang dicantumkan memiliki keseimbangan antara ukuran internal dan eksternal. Selain berfungsi untuk memperjelas strategi, balanced scorecard juga dapat digunakan sebagai alat pengukuran kinerja, dengan cara membandingan target dengan kinerja yang dicapai.

Dengan adanya ukuran-ukuran yang digambarkan dalam strategy map dan balanced scorecard, anggota dari perusahaan dapat memahami tujuan dari perusahaan serta langkah-langkah tindakan yang harus dilakukan. Hal ini dapat mendukung tercapainya tujuan perusahaan. Dalam contoh restoran cepat saji Wendy's, semboyan dari Wendy's adalah Quality is our recipe. Dimana hal ini berarti Wendy's bermaksud untuk terus menjaga dan meningkatkan kualitasnya. Efisiensi biaya merupakan salah satu kekuatan dari Wendy's. Namun efisiensi biaya ini tentunya tidak dilakukan dengan mengorbankan kualitas dari produk yang dihasilkan. Dengan adanya kekuatan yang dimiliki, Wendy's menetapkan salah satu strategi berupa pengembangan produk baru dengan memperhatikan efsiensi biaya dan tetap mempertahankan konsistensi kualitas produk. Dengan keberhasilan peluncuran produk baru ini diharapkan profitabilitas perusahaan dapat meningkat.

\section{Keterbatasan Penelitian dan Saran}

Penelitian ini menggunakan data dari restoran cepat saji Wendy's pada tahun 2013. Hal ini membuka kesempatan bagi peneliti selanjutnya untuk melakukan penelitian dengan menggunakan data terbaru disesuaikan dengan perkembangan situasi dan kondisi. Peneliti selanjutnya juga dapat menggunakan restoran cepat saji lainnya sebagai bahan pembanding dari restoran cepat saji Wendy's. 
Jurnal Akuntansi Maranathaø Volume 10 Nomor 1, Mei 2018 : 53 - 61

\section{Daftar Pusataka}

Ajmi et al. 2013. Wendy's Analysis. MBAD 271: Strategic Management

Anthony, R \& Govindarajan, V. 2007. Management Control Systems. New York: McGraw Hill

Hilton \& Platt. 2015. Managerial Accounting: Creating Value in a Dynamic Business Environment. New York: McGraw Hill

Horngren, Datar, Foster, Rajan, and Itner. 2015. Cost Accounting: A Managerial Emphasis. Pearson International Edition : Prentice Hall

Poureisa, Ahmadgourabi, Efteghar. 2013. Balanced Scorecard: A New Tool for Performance Evaluation. Interdisciplinary journal of contemporary research in business vol 5 no 1

Zizlavsky, Ondrej. 2014. The Balanced Scorecard :Innovative Performance Measurement and Management Control System. J.Technol.Manag.Innov.2014.Volu me 9. Issue 3

https://balancedscorecards.com/strategymap/\#strategy-map-overview

https://www.qsrmagazine.com

https://www.wendys.com 